\title{
INTERNET BASED LEARNING DURING COVID-19 PANDEMIC IN EFL CLASSROOM
}

\author{
Cucum Rohmawati \\ SMK Negeri 3 Kota Serang \\ Serang City, Indonesia \\ cucumrohmawatispd@gmail.com
}

\begin{abstract}
Indonesia is in Pandemic of Covid-19 which make many activities should be limited to stop the spread of virus and decrease the number of victims and death. The government implemented a new policy that is work from home and study for home for students in all education institution, includes vocational high school which students are EFL learners. Teaching learning activities should be implemented although the teachers and students are in different places. So, internet based learning should be used. Therefore, this article aims to analyze internet based learning during Covid-19 Pandemic in EFL Classroom. This study used qualitative approach, and case study was chosen as research method. The data was taken from Two English teachers and fifteen studentsin SMKN 3 Kota Serang thorugh observation and interview. Activities in qualitative data analysis were carried out interactively and continuously to completion which was described in four steps. The four steps are data collection, data reduction, data display, and verification or conclusion. The result found that in implementing internet based learning is ineffective due to some problems, they are students inactive, internet tools, internet access or quota and also control from stakeholders. Dealing with those problems, the teachers can implement several ways to make internet based learning more effective and students can comprehend their English skill although they don't learn directly. The ways that teacher should try consist of: (1) doing exploration, (2) doing enactment, and the last (3) doing evaluation.
\end{abstract}

Keyword: Covid-19 Pandemic, Internet Based Learning, EFL learners

\section{INTRODUCTION}

Indonesia is facing a pandemic, where's an epidemic occurring on a scale that crosses international boundaries, usually affecting people on a worldwide scale (Porta, 2008, p. 179). It's caused by Corona Virus Desease-19 (Covid-19) which widespread and kills many people. It's set in a state of this pandemic based on Presidential Decision No. 2, 2020 which determines the spread of Covid-19 virus as national non natural disaster. A coronavirus which is known as Covis-19 is a kind of common virus that causes an infection in the nose, sinuses, or upper throat has spread so fast and to almost all countries. the World Health Organization identified SARS-CoV-2 as a new type of coronavirus in early 2020, after a December 2019 outbreak in China.

The World Health Organization stated that Covid-19 is a disease caused by SARSCoV-2 that can trigger what doctors call a respiratory tract infection. It can affect upper respiratory tract (sinuses, nose, and throat) or lower respiratory tract (windpipe and lungs). It spreads the same way other coronaviruses do, mainly through person-to-person contact. 
Universitas Banten Jaya

Infections range from mild to deadly (Pathak, 2021).

Irwandy (2021) stated that Indonesia has a fairly high death rate due to Covid-19, the number reaches $36 \%$. That case make Indonesia decides to carry out large-scale social restrictions where the organizations and institutions should implement a new policy to ask the employee to work from home, the students study from home, limited public services, and other strict health protocols to stop the spread of Covid19. It means that the activities of society are limited including teaching and learning activities at school where the students learn from home by using internet as a media.

Internet based learning means an individuals' confidence and self-belief in their ability to master an online course or online learning activity (Yukselturk \& Bulut, 2007, p. 71-83). In another side, a study conducted by Chun, Kern, and Smith (2016) summarizes internet based learning as a distance learning where education system separate learners from the educator and the learning process by using various resources through Information and Communication Technology (ICT). It can be concluded that internet based learning is a system of education which electronic use internet-based technology or ICT in teaching learning activities for organizing learning classes to reach a broad and massive group of students where the teacher and students carry out learning together, at the same time, but in different places.

Internet based learning itself has several characteristics as stated by Dabbagh and Bannan-Ritland (2005) who proposed the characteristics of internet based learning which consist of: (1) constructivism which holds that learning occurs when learners construct meaning, (2) social interaction and collaboration which is required within a problem-based learning framework, students must depend on each other to reach the learning objective, (3) internet based learning give opportunities for disabilities learners to participate in teaching learning process, (4) internet based learning needs information and technology tools to support students to learn in the distance, (5) incorporates electronic devices and software among teachers and students, (6) in doing teaching learning process, there is interactivity where the students works together and give influence each other, (7) the students need to be self- subsistence and maintenance and be independence, (8) internet based learning is easy to be accessed, approached and used by the teachers and students to do interaction whether they are in a distance, (9) internet based learning improves and enhances students for being enriched. 
Universitas Banten Jaya

Internet based learning is a new thing of for several English teachers who used to organize teaching learning activities face to face in the classroom, especially in dealing with foreign language students of vocational high school. So, they need to improve the quality of their teaching by selecting suitable internet application which is easy for students to access and provide students more opportunities to learn.

Various applications and platforms which is usually used are google classroom, google meet, zoom WhatsApp, telegram, and sometime Facebook and Instagram also used by the teacher to get teaching learning process easier. But the fact shows that internet based learning creates several difficulties and problems. A study conducted by Ahmad (2016) found a phenomenon that EFL learning which requires a lot of practice for its application also experiences obstacles when the learning system is applied. In reading session, for example, the ICT equipment used by teachers to train students who are in separate and distant places is often ineffective, where the teachers provide the material through google classroom but several students can't access it easily. A research carried out by Nashruddin, Alam, and Tanasy (2020, 182-194) confirms that some students live in remote rural areas that are not covered by the internet.
In addition, their cellular network is sometimes unstable, due to the geographical location which is quite far from the signal coverage. This is also a problem that occurs in many students who are doing internet based learning, so the implementation is less effective. Teachers also cannot maximally supervise students when giving listening exams, because when the teachers try to use voice note through WhatsApp application, it's limited in time and size, so the example given by the teacher is not maximally sent. Then, when the teachers try to use Instagram or YouTube, the students feel difficult in their quota to access. It's clear that in listening skill, the students are less to comprehend during internet based learning.

For speaking skill, when the teachers try to use google meet or zoom to meet students, students also find problems in imitating the way of speaking exemplified by their teacher, and the teacher also cannot optimally train the students to speak because of unstable network or inadequate devices which make the ongoing meeting heard unclear in sound and also the video is sometimes buffering.

Not only that, the absence of the internet quota is also a problem that often happens. Providing internet quota requires a high cost. This difficulty is felt by students and parents from middle to lower class 
Universitas Banten Jaya

economies. They do not have adequate budget to provide the internet network. The government has tried to solve this problem by giving the students quota from Education and Culture Ministry. But unfortunately, the quota is difficult to use for some application.

From the problems above, it can be seen that the role of teacher can't be replaced by technology. It will be a big challenge for English teachers to know and implement the best way to motivate students to learn English in this pandemic era by using internet based learning so the learning objectives still can be reached.

The explanation above is the reason why the researcher purposes to conduct a research about internet based learning, because the teacher can avoid to conduct it in their teaching learning process due to the situation of covid-19 pandemic which forces to stop the spread of it.

\section{METHOD}

In conducting this research, qualitative approach is used. The case study was chosen as the research method in this study, which was conducted at SMKN 3 Kota Serang which was one of vocational high school in Serang City from January to June 2021. Two English teachers and fifteen students from $10^{\text {th }}, 11^{\text {th }}$, and $12^{\text {th }}$ grade were purposively chosen as the participants. The fifteen students were selected as the respondents based on their liveliness during internet based learning in Pandemic era. Creswell (2008) stated that qualitative research is a process of scientific research that is intended to understand human problems in a social context by creating a comprehensive and complex picture presented, reporting detailed views of sources of information, and carried out in natural settings without any intervention from researchers. Meanwhile, Gustafsson (2017) stated that a case study can be defined as an intensive study about a person, a group of people or a unit, which is aimed to generalize over several units.

In this research, literature study, observation and interview with SMKN 3 Kota Serang teachers and students are carried out to obtain the necessary data. The data are reduced, displayed, and verified or concluded. Member checking was done by taking the conclusion or information back to the participants so that they could determine the accuracy of the conclusion.

\section{DISCUSSION}

In simple terms, internet based learning can be interpreted as a learning program that is almost part or all of the material learning is sent online (Ellen and Seaman, 2007: 4). It means that internet based learning is a program of organizing 
online learning classes to reach massive groups and wide target. It has become an inevitable choice for education institutions during Covid-19 Pandemic, where the teachers can still teach, and students can still study in their own places without being together in the classroom as they do in the classroom. It made teaching learning activities highly dependent on the availability of information and communication technology and internet access.

In implementation of internet based learning in EFL Classroom for students of vocational high school, there are several problems found by the English teachers.

The first problem comes from students. Several students are audio visual learner where they need to read the material and listen the explanation of it from the teacher directly, when the students should be active in internet based learning to achieve learning goals. So, they need to be skilled in using information and technology tools as media for learning, they have to be able to access internet for running the application needed for learning, they also have to understand the essential of communication and collaboration although they and their friends are in the different places.

Not only that, many students come from low economic where they are difficult to have internet tools as media for learning such as laptop, smart phone, internet connection or quota. So, it is found that teaching learning process doesn't run smoothly.

After that, when the teachers have given the material and explanation and then try to evaluate students understanding, students are often found to do plagiarism. They copy what they found from a web and then submit it without any paraphrase.

The second problem comes from the teacher. It is found that the difficulties in using ICT not only for students, but also the teachers. There are several teachers who don't able to operate computer and smartphone well. Not only that, there are also some teachers who just can use google classroom and WhatsApp in teaching English without knowing what students' need to comprehend their English skill

It can be seen that google classroom just focus on reading and writing. Because reading and writing consist of grammar and structures which offer a series of rules of the language that allow us to understand and formulate the proper words (Zhang, 2013). Teacher can explain and give explanation of them through google classroom or WhatsApp. It's effective enough because students can access it anytime. 
Universitas Banten Jaya

In another side, it's difficult to teach speaking and listening, where there are pronunciation and fluency strengthen the language proficiency of the individuals and their communicative skills more clearly. They are both so closely related that they are inseparable (Abbaspour, 2016).

Media used for teaching speaking and learning which only use google classroom and WhatsApp make teaching learning activities of speaking and listening don't not run smoothly. The teachers ever use zoom and google meet or WebEx but only $40-50 \%$ students can join, and it's affected on students' speaking and listening itself. Some of them try to use WhatsApp, but it is not suitable because it just connects for as many as 4 to 8 person. So, the interaction among all students are limit.

Whereas speaking should be mastered by students of vocational high school because speaking is the most critical ability to learn (Savitri, 2013; Nuraini, 2016) because they will deal with many job workers when they've graduated and speaking ability will make them competitive. And in this case, the teacher should figure out how they interpret their teaching and affect their practice. Confidence in classrooms where teachers are not comfortable in their teaching practices might play an essential role. But for EFL learners in this internet based learning, it doesn't run smoothly.

The third problem comes from government and education institution and students' parents

There is no control of the implementation of internet based learning. In google classroom which I mostly used by many teachers, the discussion is only done among the teachers and students. Many students are absence for some meetings and don't submit the task as evaluation of their understanding after learning, but it's just something usual. Sometimes the teachers give warning for students but most of them feel responsible of it because there is no control of stakeholder.

From students' parents, they are usual to hand over their children at school, so when they have to guide their children in their home to do internet based learning, they get difficulties and for the last, they just let their students do what they want to do without doing control about what their children learn, have they understood the material, have they able to practice speaking and listening, have they submit their children's reading comprehension toward the text and etc.

This case which happened for vocational high school students in EFL Classroom, where they should equip with particular skills or, in other words, promote 
them to have professional skills in a specific field, so that they are ready to compete in today's workplace, but they can't do it well. When teaching English in vocational high school which particularly in secondary education, should be taken into account as English for Specific Purposes (henceforth ESP) program, as Widodo (2016) has argued. For this reason, the English instructions applied in ESP teachings should be totally different from general English (GE). Instructions which is very general in nature; serving the students with the teaching of all four language skills and stressing them equally (Esfandiari, 2015; Rahman, 2015).

All problems happened in the place of this research have similar problems the previous study conducted by. Ahmad (2016) where the teachers don't have enough ability to use technology in online learning, not all teachers are capable of operating computers or gadgets to use in online learning activities, the teacher also cannot optimally train the students to speak, students' parents and students do not have computer or android device.

The problems are also found in another previous study from Nashruddin, Alam, and Tanasy (2020) which confirms that some students live in remote rural areas that are not covered by the internet. And in a research conducted by Wahab and
Iskandar (2020) found that there is a demand for the fulfillment of educational services for students, as mandated in the constitution. On the other hand, they are faced with a lack of supporting facilities. The problem is not only in the lack of learning equipment or facilities, but also in the absence of the internet quota, and when the teachers do evaluation as the last step in teaching learning activities, it's found that several students do plagiarism. The just copy from the internet what they have submitted without paraphrasing, the students just follow the regulation of assignment without knowing the essential point of evaluation conducted by the teacher.

It's a big challenge for English teacher where internet based learning doesn't run maximally but the students need to have high skill in English to support them to get a good job after graduating.

From the discussion and problems happened during internet based learning, it can be summarized that it's not effective enough especially when it's conducted for vocational high school students who are EFL learners.

But the teacher can minimize that ineffectiveness by doing some strategies which may help them and their students to improve the quality of English teaching 
learning process to help students easier in comprehend their English skills.

The English teacher apply Integrative Learning Deign Framework for Online Learning (ILDF) from Dabbagh dan Bannan-Ritland (2005:49) as the following picture:

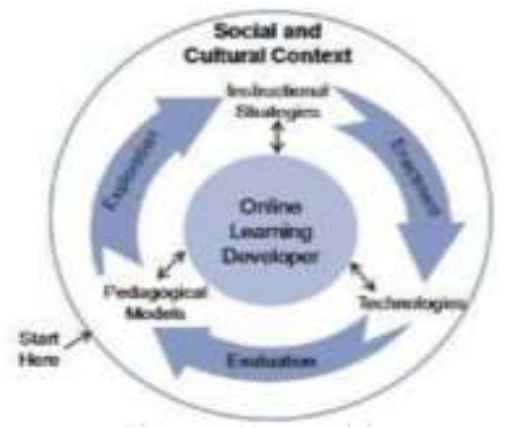

From the picture, the English teacher should do some steps. The first thing that teachers should do exploration to understand what students' need. This is about how students build their knowledge and memorize what they learn. In this step, the teacher should identify all information related the situation of internet learning based test, it's supporting tools, students' environment, materials, learning objectives. It will make teachers easier know how to stimulate students to be active in learning based internet, what the best strategies and suitable application to do teaching learning activities.

Then, the teacher should enactment. In this step, the teachers do all of information gathered during the exploration phase regarding to learning process are mapped, the existing pedagogical content and models was being identified in order to apply an effective online learning strategies. Tis step will let teachers know the best strategies that they have to do based $\mathrm{n}$ students need and students' facilities related to $\mathrm{o}=$ internet based learning. So, with specific strategies decided, the teacher will be able to decide suitable technologies for doing teaching learning process which can be evaluated later.

The last step is evaluation. This is the main activity which shows whether the learning objectives achieved or not. Through this step, the teacher will know how effective teaching learning process is, wat skill that students have and haven't comprehended. It can be used for the teachers as report to the education institution and students' parent to do improvement. But it should be done periodically in order to make teaching learning process be integrated and make it more effective and students can improve their English skill although learning is carried out at a distance, without face to face, the learning objectives are still achieved.

The solution of internet based learning from Dabbagh dan Bannan-Ritland (2005) has been implemented in the study of Syaiputra Wahyuda Meisa Diningrat 
Universitas Banten Jaya

(2019) and it made internet based learning or online learning be integrative to make teaching learning environment be more effective, structured, directed with clear goals so learning objectives will be achieved.

\section{CONCLUSION}

This study examined that internet based learning in teaching learning activity for vocational high school students in EFL classroom is less effective. There are several problems found includes students inactive, internet tools and quota of students, inability of English teachers to use suitable ICT, and there is no control from government, education institution and also students' parents. Dealing with those problems, the English teacher can implement several strategies to make teaching learning activities based internet more effective, the strategies consist of: (1) doing exploration, (2) doing enactment, and the last (3) doing evaluation.

This study shows that more research need to be conducted in the area of improving communications and utilizing multi-media to enhance internet based learning for not only students but also the teachers as educational experiences in regard to learning course content, interactivity, students' independence, accessibility, and enrichment to support the effectivity of digital classroom.

\section{REFERENCES}

Abbaspour, F. (2016). Speaking competence and its components: A review of the literature. International Journal of Research in Linguistics, Language Teaching, and Testing, 1(4).

Ahmad, S. Z. (2016). The Flipped Classroom Model to Develop Egyptian EFL Students' Listening Comprehension. English Language Teaching, 9(9), 166-178.

Chun, D., Kern, R., \& Smith, B. (2016). Technology in Language Use, Language Teaching, and Language Learning. The Modern Language Journal, 100, 64-80.

Cresswell, John W. (2008). Educational Research: Planning, Conducting and Evaluating Quantitative and Qualitative Research, 3rd ed. New Jersey: Pearson Merril Prentice-Hall.

Dabbagh, N., \& Bannan-Ritland, B. (2005). Online Learning: Concepts, Strategies, and Application. Upper Saddle River, NJ.: Pearson/Merrill/Prentice Hall.

Ellen, E \& Seaman, J. (2007). Online National: Five Years of Growth in Online Learning. Needham: Sloan Consortium.

Esfandiari, R. (2015). An Investigation into ESAP Needs of Iranian BA Students of Law. The Journal of Teaching Langauage Skills (JTLS), 7(3), 2959.

Gustafsson J. (2017) Single case studies vs. multiple case studies: a comparative study (Thesis). Sweden: Halmstad University

Irwandy. (2021). Tingkat Kematian Akibat Covid-19 di Indonesia Capai 36 
Universitas Banten Jaya

Persen, Ini Penyebabnya

Diakses tanggal 7 Agustus 2021 dari https://www.kompas.com/sains/read /2021/07/29/160600923/tingkat-

kematian-akibat-covid-19-diindonesia-capai-36-persenini?page $=$ all

Nashruddin, N., Alam, F. A., \& Tanasy, N. (2020). Perceptions of Teacher and Students on the Use of E-Mail as A Medium in Distance Learning. Berumpun: International Journal of Social, Politics, and Humanities, 3(2), 182-194.

Nuraini, K. (2016). The barriers of teaching speaking English for EFL learners. ELLITE: Journal of English Language, Literature, and Teaching, 1(1).

Pathak, Neha MD. (2021). Coronavirus and COVID-19: What You Should Know. Diakses tanggal 5 Agustus 2021 dari https://www.webmd.com/lung/coro navirus

Porta, Miquel, ed. (2008). Dictionary of Epidemiology. Oxford University Press. p. 179. ISBN 978-0-19531449-6

Rahman, M. (2015). English for Specific Purposes ( ESP ): A Holistic Review. Universal Journal of Educational Research, 3(1), 24-31. https://doi.org/10.13189/ujer.2015.0 30104

Savitri, A. S. (2013). The use of language games to improve the students' speaking ability of class VII a of SMP Ma'arif terpadu Muntilan in the academic year of 2012/2013. [Doctoral dissertation]. Yogyakarta State University, Yogyakarta.

Widodo, H. P. (2016). Teaching English for Specific Purposes (ESP): English for Vocational Purposes (EVP). In W. A. Renandya \& H. P. Widodo
(Eds.), English Language Teaching Today: Linking Theory and Practice (pp. 277-291). Springer International Publishing. https://doi.org/10.1007/978-331938834-2_19

Wahab, S. and Iskandar, M. (2020). Teacher's Performance to Maintain Students' Learning Enthusiasm in the Online Learning Condition. JELITA. 1, 2 (Aug. 2020), 34-44.

Yukselturk, E. \& Bulut, S. (2007). Predictors for student success in an online course. Educational Technology \& Society, 10, 71-83.

Zhang, B. (2013). An analysis of spoken language and written language and how they affect English language learning and teaching. Journal of Language Teaching \& Research, 4(4) 
Journal of English Language Teaching and Literature (JELTL)

P-ISSN 2623-0062

Volume 4 No. 2, August 2021

E-ISSN 2622-9056

Universitas Banten Jaya 